\title{
THE GENERAL RULE ON CHOICE OF LAW FOR NON-CONTRAC- TUAL OBLIGATIONS IN LEGISLATION OF EUROPEAN UNION AND BOSNIA AND HERZEGOVINA
}

\section{Jasmina Alihodžić}

Faculty of Law Tuzla, University of Tuzla
Scientific review

UDC: 341.9(497.6:4-67 EU)

Received: 01.12.2013.

\begin{abstract}
The project of unification of private international law on the level of European Union encompassed bringing of unique choice of law rules, among others, in the area of non-contractual obligations with international element. A communitarian legislator chose a set of flexible choice of law rules that enable satisfaction of the principle of legal certainty together with the establishment of a balance between persons claiming to be liable and sustaining damage. PIL Act that is being enforced in Bosnia and Herzegovina in relation to the subject of this paper alternatively determines the law applicable to non-contractual obligations, according to the law of the place where the harmful act was done or the law of where the consequence occurred, depending on which of these two laws is more favorable to the person sustaining damage. The author of this paper points out the evident discrepancy in the general rules of determination in EU legislation and Bosnia and Herzegovina, and the need to harmonize legislation in this field with the acquis communautaire, arising from the Stabilization and Association Agreement.
\end{abstract}

Key words: lex loci damni, habitual residence, lex loci delicti, Rome II Regulation, PIL Act.

\section{INTRODUCTION}

Legislative activity directed toward making the instrument that would equalize, and in the final unify rules of private international law in the field of non-contractual obligations began nearly four decades with the adoption of the first draft of the Convention on the law applicable to non-contrac-

\footnotetext{
${ }^{1}$ Correspondence to:

Jasmina Alihodžić, Faculty of Law Tuzla, University of Tuzla

Tuzla, Bosnia and Herzegovina

Phone: +38761 730566

E-mail: jasminaalt@hotmail.com
}

tual obligations. The project of harmonization of rules of private international law in this area is completed with the adoption of EC Regulation No. 864/2007 of the European Parliament and the Council on the law applicable to non-contractual obligations $^{2}$.

\footnotetext{
${ }^{2}$ The draft of Convention was presented on 6 December 1972. More on the activities that preceded the adoption of the Rome II Regulation see in: Kunda, I, Rome II Regulation: uniform rules on the law applicable to non-contractual obligations in the European Union, Journal of Law, University of Rijeka, Vol. 28, No. 2, the 2007, pp. 1270-1274. See also in Šaula, V., Applicable Law for non-contractual obligations - current trends in community law, Yearbook of Law Faculty, University of Banja Luka, No. 30/2007, pp. 120 - 121. See in Von Hein, J., Of Older Siblings and Distant Cousins: The Contribution of the Rome II Regulation to the Communitarization of Private International Law, RabelsZ Bd. 73, 2009, pp. 463 - 466.
} 
The project of harmonization of rules of private international law in this area is completed with the adoption of EC Regulation No. 864/2007 of the European Parliament and the Council on the law applicable to non-contractual obligations ${ }^{3}$.

Given that the Rome II Regulation can be considered the oldest relative in the family of European secondary legislation when it comes to choice of law rules of private international law, there is evidence of its role in regulation model in terms of determination of general principles and further influence on the process of communitarization of private international law in general ${ }^{4}$.

Following, it was necessary that rules on the law applicable to non-contractual obligations are compatible with the communitarian rules on jurisdiction and recognition and enforcement of judgments in civil and commercial matters, as well as regulations relating to the law applicable to contractual obligations ${ }^{5}$. However, although it is evident that there is a need for choice of law rules in the Member States to define the same national law irrespective of the country where the action was brought, which is a condition for the proper functioning of the internal market in order to improve the predictability of the outcome of litigation, security in terms of the applicable law and free movement of judicial decisions ${ }^{6}$ it seems, however, that we cannot talk about the full compatibility of the provisions of the Rome II Regulation and the Brussels I Regulation relating to jurisdiction. The provisions of Article 5 Paragraph 3 Brussels I Regulation and Article 4 Paragraph 1 Rome II Regulation are the most obvious examples of different application of these two instruments. While the first act, committed to the principle of ubiquity, offers the possibility that the claimant in cases concerning the harmful acts, delicts or quasi - delicts, is suing the other side before the courts of the place where the harmful act was done or can be done, Article 4 Paragraph 1 Rome II Regulation provides that the law applicable for non-contractual obligations arising from delict, is the law of the country in which the damage occurred, regardless of the country in which the event occurred that caused all the damage and regardless of the country(ies) in which indirect consequences of that event occurred.

${ }^{3}$ Regulation (EC) No 864/2007 of the European Parliament and of the Council of 11 July 2007 on the Law Applicable to Noncontractual Obligations (Rome II), Official Journal L 199/40, 31. 7. 2007., further on: Rome II Regulation.

${ }^{4}$ Von Hein, J., Of Older Siblings and Distant Cousins: The Contribution of the Rome II Regulation to the Communitarisation of Private International Law, RabelsZ Bd. 73, 2009, p. 464 - 466.

${ }^{5}$ See Item 7 Preamble of the Rome II Regulation.

${ }^{6}$ See Item 6 Preamble of the Rome II Regulation.
Incompatibility of Community acts listed is evident in the case of determining the material scope of application of regulations. In fact, while Article 5 Paragraph 3 Brussels I Regulation certainly applies when it comes to determining the specific responsibilities in case of damages resulting from the violation of personal rights (violation of privacy rights, rights of personality, including defamation), this segment of non-contractual obligations is excluded from the field of application of the Rome II Regulation ${ }^{7}$. Because of the need to satisfy the requirements of legal certainty and fairness in individual cases, which in final represents essential components of justice area and proper functioning of the internal market, this Regulation provides for attachment points that seem most appropriate for achieving those goals. This set of choice of law rules is a flexible framework within which it is enabled for the court, before which the dispute is taken, to act in certain cases appropriately. Consequently, the Regulation provides for a general rule to determine the applicable law for non-contractual obligations, as well as specific rules for specific harmful actions in a situation where the general rule does not allow the establishment of a reasonable balance between the interests of the persons concerned. In addition, the Regulation in the form of "escape clause" in certain cases, allows exceptions to this rule in cases when it is clear from all the circumstances of the case that a damaging action is obviously closely connected with another country ${ }^{8}$.

The solutions that are provided in the legislation of Bosnia and Herzegovina (hereinafter: $\mathrm{B} \& \mathrm{H}$ ) with respect to the determination of the law of non-contractual obligations largely deviate from the above mentioned Communitarian rules. The legislator in fact opted for the construction which favors a person sustaining damage in such a way that the applicable law may be the law of place where the harmful act was done or the law of place where the consequence occurred, depending on which of the two laws is more favorable to the injured party. The paper provides a detailed analysis of the general rules for determining the applicable law for non-contractual obligations under the Rome II Regulation and the PIL Act which came into force in Bosnia and Herzegovina ${ }^{9}$, differences that exist in a given solutions, then the proposals de lege ferenda indicating the possibilities and obligations of legislative intervention in terms of legislative reform in this area.

\footnotetext{
${ }^{7}$ See Article 1 Paragraph 2 paragraph (g) of the Rome II Regulation. Von Hein, J., op. cit. $470-471$.

${ }^{8}$ See Item 14 Preamble of the Rome II Regulation.

${ }^{9}$ More on this law see the part of the work which relates to legislation in $\mathrm{B} \& \mathrm{H}$.
} 
General Choice of Law Rule for Non-contractual Obligations according to Rome II Regulation

Law applicable to non-contractual obligation arising out of tort is the law of the country in which the damage occurred, regardless of the fact where the harmful event occurred that caused the damage, and regardless of where the indirect consequences of that event occurred ${ }^{10}$. In other words, the law of the country where the direct damage occurred (lex loci damni) is applicable, where in the context of the general rule the laws of the country where the harmful event occurred is irrelevant, or the law of the country where indirect consequences of the event took place. Although in most member states as the basic solution for non-contractual obligations the rule of lex loci delicti commissi is accepted, the practical application of this principle in terms of the existence of divergent views regarding the interpretation of this principle by the legislative and judicial authorities, differs when the factual circumstances of this case relate to territory of several states, which in the end can lead to legal uncertainty regarding the choice of applicable law ${ }^{11}$. This would be the case if, for example, the wrongful event occurred in one, and the consequences of that event in another country. In this sense, the uniform rules, which represent a compromise, or a reasonable balance between the interests of a person who is considered to be responsible and a person who has suffered damage can ensure predictability of judicial decisions, and thus legal security if the law applicable to non-contractual obligations from torts is being determined in accordance with the principle of lex loci damni, by establishing a general rule to the point of direct damage. The Regulation, however, does not give an explicit interpretation of the concept of direct damage.

\footnotetext{
${ }^{10}$ Article 4 Paragraph 1 Rome II Regulation.

${ }^{11}$ See more in: Von Hein, J., pp. 476 - 480 Kramer, X., The Rome II Regulation on the Law Applicable to Non-Contractual Obligations: The European private international law tradition continued, Nederlands Internationaal Privaatrecht, No. 4, 2008. Rome II Regulation - Communitarization of European Delictual Law - Historical Sheme and General Legal Frame, Collection of Papers, Faculty of Law in Split, 45, No. 2, 2008. Kunda, I., Rome II Regulation: Unified Choice of Law Rules for Non-contractual Obligations in the European Union, Collection of Papers, Faculty of Law in Rijeka, Vol. 28, No. 2., 2007. Alihodžić, J., Development of European Private International Law: Directions for the Reform of the Legislation in Bosnia and Herzegovina, OFF-SET, Tuzla, 2012.
}

The Regulation, however, does not give an explicit interpretation of the concept of direct damage. Specifically, point 17 Preamble to the Rome II Regulation stipulates that "the applicable law should be determined on the basis of where the damage occurs, regardless of the country or countries in which the indirect consequences could occur. Accordingly, in cases of personal injury or damage to property, the country in which the damage occurs should be the country where the injury was sustained or the property was damaged respectively".

As the preamble to Rome II Regulation instructs in terms of achieving consistency between this and other instruments of Communitarian law governing the issue of jurisdiction, recognition, enforcement and the instruments dealing with the law applicable to contractual obligations ${ }^{12}$, the interpretation of Article 5 Paragraph 3 Brussels I Regulation by the European Court of Justice can serve as a guideline for establishing a discrepancy between direct and indirect damage in terms of the application of Article 4 Paragraph 1 Rome II Regulation. Thus, the European Court of Justice in the case Dumez France SA and Tracoba SARL v. Hessische Landesbank and others ${ }^{13}$ determined that for purposes of the provisions of Article 5 Paragraph 3 Brussels I Regulation the only relevant is "the place where the harmful event, which caused delictual or quasi-delictual responsibility, directly caused harmful effects to a person who is directly damaged by this event"14. In terms of the proper application of these provisions, it is necessary to determine its scope of application. Specifically, if one takes into account that for special cases of noncontractual obligations for damages specific rules are prescribed (product liability, unfair competition and acts restricting free competition, environmental damage, violation of intellectual property rights and industrial action), clearly the general rule established by this Regulation is applied to those cases of non-contractual obligations for harmful actions that are not regulated by Articles 5 - 9 of Rome II Regulation ${ }^{15}$.

\footnotetext{
${ }^{12}$ Item 7 Preamble of the Rome II Regulation.

${ }^{13}$ Dumez France SA and Tracoba SARL v. Hessische Landesbank and others, C-220/88, (1990) E.C.R., 49. V. i Antonio Marinari v. Lloyds Bank Plc and Zubaidi Trading Company, C- 364/93, (1995), E.C.R. I - 2719.

${ }^{14}$ More on the facts of abovementioned case see in: Grušić, U., Rome II Regulation of the European Union: The Law Applicable to Non-contractual Obligations, Annals of the Faculty of Law in Belgrade, year LVII, No. 1/2009, pp. 173 - 174.

${ }^{15}$ Hohloch, G., The Rome II Regulation: an Overview, Place of Injury, Habitual Residence, Closer Connection and Substantive Scope: the Basic Principles, Yearbook of Private International Law, Vol. 9., 2007, pp. 9.
} 
However, here one should bear in mind the fact that a number of Member States continue to apply the provisions of other international documents governing the identical matter, such as the Hague Convention on the law applicable to road traffic accidents from 4 May $1971^{16}$, in accordance with Article 28 Regulation $^{17}$.

The application of the general rules on determining the law applicable to non-contractual obligations can lead to certain inconsistencies, and in this sense it is necessary to distinguish between two situations ${ }^{18}$. Namely, if one harmful event causes immediate damage in several states, the principle of "mosaic"19 is applied, or it leads to cumulative application of the law of all the states concerned, and in the way that the law of each state shall be applied to the issues raised on the occasion of damage in the state in which it happened ${ }^{20}$. However, if it is justified given the circumstances of the case, it is possible to apply one law to all questions by means of an escape clause ${ }^{21}$.

Conversely, if more harmful events that occurred in different states cause immediate damage in one state, the application of the general rule is clear, given that the law of the country(ies), in which the harmful events took place, is not relevant in terms of determining the applicable law in accordance with the principle of lex loci damni.
Certain difficulties may possibly occur if such a question is raised in terms of the application of special rules for specific types of torts, such as with the environmental damage ${ }^{22}$. Calling the escape clause in this and similar cases is not possible, because the provision of Article 4 Paragraph 3 cannot be applied to special cases of harmful actions ${ }^{23}$.

The rule of lex loci damni as a general rule for determining the applicable law for the delicts will not be applied if both the person who is claimed to be responsible and a person who suffers damage have their habitual residence in the same country at the time of occurrence. In this case the law of the state of the habitual residence of both parties of noncontractual relation will be applied ${ }^{24}$.This solution is in accordance with the rules of private international law of many EU member states ${ }^{25}$. In addition, the deviation from the general principle in favor of the habitual residence of the parties is in accordance with the principle of judicial economy, because the application of paragraph 2 Article 4 , if it satisfies the requirements, implies lower litigation costs, more efficient judicial process, and international compliance decisions ${ }^{26}$.

${ }^{22}$ Article 7 Rome II Regulation states: " The law applicable to a non-contractual obligation arising out of

environmental damage or damage sustained by persons or property as a result of such damage shall be the law determined pursuant to Article 4(1), unless the person seeking compensation for damage chooses to base his or her claim on the law of the country in which the event giving rise to the damage occurred.

${ }^{23}$ Von Hein, J., op. cit., pp. 476.

${ }^{24}$ Article 4 Paragraph 2 Rome II Regulation.

${ }^{25}$ See for example Article 40 (2) of the Introductory Act to the Civil Code of Germany 21 September 1994 which states: "If, at the time of occurrence of harmful event a person claimed to be liable and a person who suffers damage are habitually resident in the same state, the law of that State is applicable. In the case of companies and other bodies created by enrolling in the registry or without registration, place of habitual residence shall be the place of central administration, or in the case of business branches, the place in which the branch is located. Acc. to: Jayme, E., Hausmann, R., Internationales Privat - und Verfahrensrecht, Verlag CH Beck, Munich 2010, pp. 37. See also Article 99 paragraph 1 No. 1 of the Belgian Act on Private International Law: "The law applicable for non-contractual obligations is:

1. The law of the State in whose territory a person claimed to be liable and a person who suffers damage are habitually resident at the time the harmful event occurred." Acc. to: Yearbook of Private International Law, Vol. VI, 2004, pp. 358.

${ }^{26}$ Acc. to Von Hein, pp. 481. 
Rome II Regulation does not give an autonomous meaning of habitual residence for natural persons, and thus, this term is interpreted in accordance with the rules of national laws ${ }^{27}$. However, when it comes to a natural person acting in the scope of its business activities, then habitual residence is considered to be its principal place of business ${ }^{28}$. When it comes to companies and other bodies created by enrolling in the registry or without registration, habitual residence shall be the place of their central administration. If an event that caused the damage occurs or damage occurs within the business of a branch, affiliates or any other business establishment, the place in which the branch is located, representation, or any other business establishment is considered a place of habitual residence. (Article 23 paragraph 1 of Rome II Regulation). Some authors ${ }^{29}$ believe that the provision of Article 4 Paragraph 2 Rome II Regulation is quite narrowly defined, and that in certain situations it can be almost completely inoperable. Specifically, the application of the provision of Article 4 Paragraph 2 Regulation takes into account the condition that both sides of non-contractual relations have habitual residence in the same state. In other words, the question is whether the application of this provision can come into consideration if these persons are habitually resident in different EU member states, which may eventually have identical legislation provisions on this issue, and the general rule established by Article 4 Paragraph 1 indicates the application of the law of a third country.

\footnotetext{
${ }^{27}$ Grušić, U., pp. 174. Cf. Article 59 Paragraph 1 Brussels I Regulation, which provides that the term of residence for the purposes of this Regulation must be evaluated under the national law of a Member State before whose court the case is brought. According to some authors, it is completely pointless to determine the concept of habitual residence for natural persons in the sense that it is given an autonomous meaning or the significance is interpreted in accordance with the law of state forum, as an "autonomous" interpretation of the Rome II Regulation, historical "background" as well as European goals determined by Articles 61 and 65 of Rome Treaty, clearly indicate that that the term "habitual residence" alludes to the factual center of life activities (Deutsch: faktische Lebensmittelpunkte), which also take into account the element of person's willingness. See in Hohloch, G., pp. 11-12.

${ }^{28}$ Article 23 Paragraph 2 Rome II Regulation.

${ }^{29}$ Symeonides, S., Rome II: A Centrist Critique, Yearbook of Private International Law, Vol. IX, 2007, pp. 156; Symeonides, S., Rome II and Tort Conflicts: A Missed Opportunity, The American Journal of Comparative Law, Vol. 56, No. 1, 2008, Von Hein, J., pp. 481 - 482.
}

Observed from a functional point of view, both situations (common habitual residence and habitual residence in different Member States, which have identical legal provisions) assume identical effect, so Symeonides following the principle of analogy suggests a positive answer to the previous question $^{30}$. However, we believe that Article 4 Paragraph 2 Rome II Regulation clearly speaks in favor of the law of the common habitual residence of the parties of non-contractual obligation, and not about "substantially identical" provisions of the various Member States. In this context, none of the exceptions to the general rule would be operational in the example above. Exclusively, it will not apply the provisions of Article 4 Paragraph 1 and 2 Rome II Regulation if all the circumstances of the case clearly point that the harmful action is obviously in closer connection with the state other than those referred to in paragraph 1 and 2, in which case it will apply the law of that other country. Manifestly closer connection with another country might be based in particular on the previous relationship between the parties, such as a contract that is closely connected with the underlying harmful $\mathrm{act}^{31}$. Difficulties that a communitarian legislator faced with when standardizing escape clause are the result of efforts to reconcile opposing views between the requirements for legal certainty on the one hand, and the need for fairness in individual cases, on the other hand ${ }^{32}$, allowing the court before which the dispute is litigated to proceed in individual cases in a flexible or convenient way.

${ }^{30}$ The explanation of the previous paragraph Symeonides gives in the example of non-contractual obligation for damages in the case when during hunting in Kenya, a French hunter injured a Belgian, who, until then, he had no legal relationship with. Suppose the French and Belgian law have the same rules on compensation, which provide much higher compensation in relation to the rules of Kenyan law. This is a classic "false conflict", where Kenya has no interest to enforce rules that allow a lower amount of compensation. In this example, the application of Kenyan law seems gratuitous, and the facts speak in favor of the application of the French or Belgian law. Similarly, Stone, P., EU Private International Law: Harmonization of Laws (Elgar European Law), Edward Elgar Publishing Ltd., 2006, pp. 347 - 348.

${ }^{31}$ Article 4 Paragraph 3 Rome II Regulation.

${ }^{32}$ Item 14 Preambule Rome II Regulation. 
In addition, the need to provide for an escape clause as a corrective of general rule was never questioned; controversial viewpoints occurred, however, in terms of determining the content, or the factors that may affect the application of the escape clause (a factor of predictability of occurrence of immediate damage, the influence of renvoi exclusion in the context of membership of some member States to the Hague Convention on the law applicable to road traffic accidents, reduction of litigation costs, etc. $)^{33}$.

Due to the fact that the first two rules of this article (lex loci damni and lex firmae habitationis communis) have the character of strict rules, and the assumption of paragraph 3 which indicates the necessity of the existence of manifestly closer connection with the law of the State other than those referred to in paragraph 1 and 2 Regulation, it is clear that the application of this rule may be considered only in exceptional situations ${ }^{34}$. The legislator further clarifies the structure of the manifestly closer connection, and in this sense exemplary states that such a connection can be based specifically on the previous relationship between the parties, such as a contract that is closely associated with the underlying harmful act, which does not exclude other legal relationships that can appear to be relevant in terms of the establishment of such links ${ }^{35}$.The Memorandum with the Proposal of the Rome II Regulation states that manifestly closer connection may exist with respect to the termination of negotiations or cancellation of a contract, or may be related to certain questions from the Family law relationships. However, it cannot be taken as a relevant relationship that exists with regard to the previous contractual relationship when it comes to individual contracts of employment or consumer contracts in respect to which the choice of applicable law is restricted by ius cogens rules of the applicable law, since the application of the closest connection principle in accordance with Article 4 Paragraph 3 Rome II Regulation would prevent the application of the protective rules in the case of weaker contracting parties (consumers, employees) in that way ${ }^{36}$.

\footnotetext{
${ }^{33}$ Von Hein, J., pp. $484-485$.

${ }^{34}$ Weintraub, R.J., The Choice of Law Rules of the European Community Regulation on the Law Applicable to Non-Contractual Obligation: Simple and Predictable, Consequence-Based, or Neither?, Texas International Law Journal, Vol. 43, 2008, pp. 405 .

${ }^{35}$ Kostić -Mandić, M., General Clause of Deviation from the Applicable Law in the Modern Private International Law, Faculty of Law, University of Montenegro, Podgorica, 2012, pp. 164165.

${ }^{36}$ See in: Explanatory Memorandum, op. cit., pp. 12 - 13. Stone, P., pp. 354
}

The escape clause is considered jurisdiction - selecting $^{37}$ rule which implies that the court, in deciding on the possibility of the application of the escape clause, may take into account only the contacts that harmful event has with different jurisdictions, and during which it cannot examine the content of the rules that exist in national laws, and that appropriateness of these rules values as a factor when deciding ${ }^{38}$.

As the application of escape clause may be considered only if the harmful act is in obvious connection with the state other than the state where the direct damage occurred, or the state where the parties have a common habitual residence, the possibility of its application in a situation where there is no prior relationship between the parties, in the sense as defined by the second sentence of paragraph 3 Article 4 Regulation is questioned. In principle, the application of the escape clause in these situations is not impossible, but it would probably be very rare ${ }^{39}$.

\section{The Law Applicable to Non-contractual Obliga- tions in the Legislation of $\mathrm{B} \& H$}

The constitution of Bosnia and Herzegovina ${ }^{40}$ made the division of competences between the state and entity levels. The initial concept from which this constitutional act starts is the enumeration of competences of the Bosnia and Herzegovina institutions (Article III / 1), with the presumption of competence in favor of the entity (Article III/3.a). In concordance with this, the area of private law relations, including issues of private international law belonged to the competence of the entities - the Federation of Bosnia and Herzegovina and the Republic of Srpska and Brčko District. After the dissolution of Yugoslavia, PIL Act ${ }^{41}$ is taken in the legislation of both $\mathrm{B} \& \mathrm{H}$ entities and so far applies unchanged.

Solutions which PIL Act provides in terms of determining the law applicable to the non-contractual obligations substantially differ from the above mentioned solutions of Rome II Regulation.

\footnotetext{
${ }^{37}$ See more in: Von Hein, J., pp. 483 - 484.

${ }^{38}$ Grušić, U., pp. 175. Kostić-Mandić, M., pp. 166-167.

${ }^{39}$ Stone, P., pp. 354. Kostić-Mandić, M., loc. cit.

${ }^{40}$ Dayton Peace Agreement signed in Paris on December, 14, 1995. More on the constitutional structure of Bosnia and Herzegovina and division of competences see in: Trnka, K., Ustavno pravo, Pravni fakultet Univerziteta u Bihaću, Sarajevo, 2000, pp. 324-325.

${ }^{41}$ Act on the Collision of Laws with Laws of Foreign Nations in Certain Cases, Official Gazzete of SFRY, No.
} 
In terms of scope of application of this Article it is considered that the provision covers all the cases of responsibility for the caused damage, and that between the participants there was no previously existed legal relationship, including quasi-contractual obligation for damages ${ }^{42}$. A special dilemma in legal theory for determining the applicable law is a compensation for damages resulting from the termination of negotiations for the conclusion of the contract, and in this sense, as previous the question of the qualifications of the legal relationship is raised. We believe that this issue should be brought under the provisions of Article 28 PIL Act ${ }^{43}$. However, a significant number of cases of non-contractual obligations for damages are excluded from the jurisdiction of PIL Act, due to the fact that in Bosnia and Herzegovina the Hague Convention on the law applicable to traffic accidents from in 1971 is in force ${ }^{44}$.

In terms of formulating a general choice of law rule for non-contractual obligations, the legislator opted for a structure which favors a person sustaining damage in a way that relevant may be the law where the harmful act was done or the law of the place where the consequence occurred, depending on which of these two laws is more favorable to the person sustaining damage (Article 28, paragraph 1 PIL Act). In terms of formulating a general choice of law rule for non-contractual obligations, the legislator opted for a structure which favors a person sustaining damage in a way that relevant may be the law where the harmful act was done or the law of the place where the consequence occurred, depending on which of these two laws is more favorable to the person sustaining damage (Article 28, paragraph 1 PIL Act). In addition, PIL Act contains a special rule for determining the law applicable to the issue of the unlawfulness of the action, in which case the applicable is considered to be the law of the place where the act was done or where consequence occurred, and if the act was done or the consequence occurred in several places, in order to protect the person sustaining damage, it shall be deemed that the action was unlawful under the law of any of these places (Article 28, paragraph 3 PILAct).

\footnotetext{
${ }^{42}$ Article 27 Paragraph 2 PIL Act

${ }^{43}$ See more in: Dika, M. (et. al.), Comment on PIL Act, Nomos, Beograd, 1991, pp. 97.

${ }^{44}$ Convention on the Law Applicable to Traffic Accidents from 4 May 1971 (further on: Hague Convention), http://www.hcch. net/index_en.php?act $=$ conventions.text $\_$cid $=81,22$ December 2012. Essén, W. E., Explanatory Report to the Convention on the Law Applicable to Traffic Accidents, http://www.hcch.net. Reese, W.L.M., Nadelmann, K.H., Draft Convention on the Law Applicable to Traffic Accidents, The American Journal of Comparative Law, Vol. 16, No. 4., 1968., pp. 588-593.
}

In addition, the PIL Act contains special rules for unjust enrichment, and management without a warrant. Thus, according to the provisions of Article 27 of PIL Act, for the unjust enrichment will be applied the law applicable to the legal relationship that is established, expected or assumed, on the occasion which led to enrichment, whereas for the warrantless management applicable will be the law of place where the manager's action was executed.

In terms of the localization of delict, the determination of the place (country) where the consequence occurred, jurisprudence, is of opinion that the place where the consequence occurred must be considered the place of violation of a protected right, but also a place where the damage occurred, if these are not the same places ${ }^{45}$. It is evident that the court practice in $\mathrm{B} \& \mathrm{H}$ accepts (also) the concept of indirect damage when determining the applicable law relating to noncontractual relationships, which is certainly contrary to solution accepted by the communitarian legislator.

\section{CONCLUDING REMARKS}

In addition to the fundamental differences that exist in terms of defining the scope of application of the Rome II Regulation, and subjects that fall under the corresponding provisions of PIL Act, it is necessary to point out the following.

Specifically, unlike the Rome II Regulation, PIL Act does not contain a provision allowing the parties to choose the law governing non-contractual obligations.

Next, renvoi is not excluded from this subject matter, so situations of reciprocation and redirection to another law are possible. We believe that B\&H legislator should carry out a thorough reform of PIL Act regarding that matter according to the pattern of communitarian solutions. One possibility, which would be a suitable solution for $\mathrm{B} \& \mathrm{H}$, is that our law refers to the relevant provisions of Rome II Regulation.

${ }^{45}$ Acc. to: Dika, M. (et. al.), pp. 100. 
Another method is the incorporation of all or some solutions of Regulation on the choice of the applicable law for non-contractual obligations in PIL Act, which would modernize the existing solutions, which is particularly important in terms of predicting special legal rules for certain types of non-contractual obligations and obligations from quasi-contract (responsibility for products, violations and restrictions on competition, environmental damage, violation of intellectual property rights, industrial action, unjust enrichment, negotiorum gestio and culpa in contrahendo), which are currently not or not adequately prescribed by our law, and in addition, the institute of party autonomy in this area of private law relations. Accordingly, for example, existing choice of law rule of Article 28 PIL Act, has given way to corresponding provision of Rome II Regulation, so that the basic rule for determining the applicable law for non-contractual obligation arising from the harmful actions would be the principle of lex loci damni, regardless of the country in which the event occurred that caused all the damage and regardless of the country or countries in which occurred indirect consequences of that event. This would substantially deviate from existing normative solutions that predict favoring a person sustaining damage, which would necessarily lead to changes in jurisdiction practice. The acceptance of communitarian standards in this area would mean that the general principle (lex loci damni) may depart in two cases, namely: first, in favor of the law of the state in which the habitual residence of persons claimed to be liable and sustaining damage is, and in favor of the law which is obviously closely connected with a given relationship, whereby the closer ties, among others, can be evaluated depending on the existence of pre-existing relationship between the parties, such as, for example, a contract that is closely connected with the harmful act. Duty to harmonize domestic legislation with the communitarian legislation in this area is not only a practical necessity, but also an obligation that according to the principle of pacta sunt servanda arises from the Stabilization and Association Agreement.

\section{REFERENCES}

Alihodžić, J., Development of European Private International Law: Directions for the Reform of the Legislation in Bosnia and Herzegovina, OFF-SET, Tuzla, 2012;

Bouček, V., Rome II Regulation - Communitarization of European Delictual Law - Historical Sheme and General Legal Frame, Collection of Papers, Faculty of Law in Split, 45, No. 2, 2008; Convention on the Law Applicable to Traffic Accidents from 4 May 1971;
Dika, M. (et. al.), Komentar Zakona o međunarodnom privatnom i procesnom pravu, Nomos, Beograd, 1991;

Essén, W. E., Explanatory Report to the Convention on the Law Applicable to Traffic Accidents, http://www.hcch.net;

Grušić, U., Rome II Regulation of the European Union: The Law Applicable to Non-contractual Obligations, Annals of the Faculty of Law in Belgrade, year LVII, No. 1/2009;

Hohloch, G., The Rome II Regulation: an Overview, Place of Injury, Habitual Residence, Closer Connection and Substantive Scope: the Basic Principles, Yearbook of Private International Law, Vol. 9., 2007;

Jayme, E., Hausmann, R., Internationales Privat - und Verfahrensrecht, Verlag C.H. Beck, München 2010;

Kadner Graziano, T., The Rome II Regulation and the Hague Conventions on Treaffic Accidents and Product Liability - Interaction, Conflict and Future Perspectives, Nederlands Internationaal Privaatrecht (NIPR), 2008;

Kostić -Mandić, M., Opšta klauzula odstupanja od mjerodavnog prava u savremenom međunarodnom privatnom pravu, Pravni fakultet Univerziteta Crne Gore, Podgorica, 2012;

Kramer, X., The Rome II Regulation on the Law Applicable to Non-Contractual Obligations: The European private international law tradition continued, Nederlands Internationaal Privaatrecht, No. 4, 2008;

Kunda, I., Rome II Regulation: Unified Choice of Law Rules for Non-contractual Obligations in the European Union, Collection of Papers, Faculty of Law in Rijeka, Vol. 28, No. 2., 2007;

Muminović, E., Međunarodno privatno pravo, Pravni fakultet Univerziteta u Sarajevu, 2006;

Nagy, C.I., The Rome II Regulation and Traffic Accidents: Uniform Conflict Rules with Some Room for Forum Shopping How So? Journal of Private International Law, vol. 6 (1), 2010; Reese, W.L.M., Nadelmann, K.H., Draft Convention on the Law Applicable to Traffic Accidents, The American Journal of Comparative Law, Vol. 16, No. 4., 1968.

Stone, P., EU Private International Law: Harmonization of Laws (Elgar European Law), Edward Elgar Publishing Ltd., 2006;

Symeonides, S., Rome II and Tort Conflicts: A Missed Opportunity, The American Journal of Comparative Law, Vol. 56, No. 1, 2008;

Symeonides, S., Rome II: A Centrist Critique, Yearbook of Private International Law, Vol. IX, 2007;

Šaula, V., Mjerodavno pravo za vanugovorne obaveze - savremena kretanja u komunitarnom pravu, Godišnjak Pravnog fakulteta Univerziteta u Banjoj Luci, br. 30/2007;

Trnka, K., Ustavno pravo, Pravni fakultet Univerziteta u Bihaću, Sarajevo, 2000;

Von Hein, J., Of Older Siblings and Distant Cousins: The Contribution of the Rome II Regulation to the Communitarisation of Private International Law, RabelsZ Bd. 73, 2009;

Weintraub, R.J., The Choice of Law Rules of the European Community Regulation on the Law Applicable to Non-Contractual Obligation: Simple and Predictable, Consequence-Based, or Neither?, Texas International Law Journal, Vol. 43, 2008;

Act on the Collision of Laws with Laws of foreign Nations in Certain Cases, Official Gazzete of SFRY, No. 43/1982, 72/82, Official Gazzete of B\&H, No. 2/92, 13/94;

Regulation (EC) No 864/2007 of the European Parliament and of the Council of 11 July 2007 on the Law Applicable to Noncontractual Obligations (Rome II), Official Journal L 199/40, 31.

7. 2007. 